\title{
Analysis of the Significance of Field Guidance Lecturers in the School Field Recognition Program in the Pandemic of Covid-19 at FIP Universitas Negeri Medan
}

\author{
$1^{\text {st }}$ Yasaratodo $\mathrm{Wau}^{1}, 2^{\text {nd }}$ Robenhart Tamba $^{2}, 3^{\text {rd }}$ Fauzi Kurniawan ${ }^{3}, 4^{\text {th }}$ Vidya Dwi Amalia \\ Zati $^{4}$ \\ \{yasaratodo@gmail.com ${ }^{1}$ \}
}

Community Education, Faculty of Education, Universitas Negeri Medan, Indonesia ${ }^{1,3,4}$, Primary

Teacher Education, Faculty of Education, Universitas Negeri Medan, Indonesia ${ }^{2}$

\begin{abstract}
This study examines the problems (1) Students' perceptions of the implementation process of the school field recognition program during the Pandemic of Covid-19 at Faculty of Education Unimed, (2) Students' perceptions of the activity process of the school field recognition program during the Pandemic of Covid-19 at Faculty of Education Unimed, (3) Students' perceptions of the meaning of the school field recognition program guidance during the Pandemic of Covid-19 at Faculty of Education Unimed. The results of previous studies explained that the results of the reflection on the implementation of the Internship Program 1 had a positive contribution to the commitment of students to prepare themselves to become the prospective educators or the educational personnel in the Community Education Study Program with an average score of 4.9 and a correlation coefficient of 0.496 , which is significant at the 95\% level, while further research explains that the students perception of the Internship Program 1 and 2 can make a positive contribution on the student learning commitment at Faculty of Education Unimed with a correlation coefficient of 0.58 which is significant at the 95 percent level. This means that Internship Program 1 and 2 have a positive impact on the student learning commitment. The latest research shows that students have a positive perception of this Kemenritekdikti Decree 123 / M.KPT / 2019 with an average score of 3.24. When the pandemic of Covid-19 hit the world, including the world of education, the effectiveness of field supervisor guidance to serve students continued to be questioned. The preliminary research data showed that the field supervisor guidance process has been effective and meaningful enough for students to make them carry out every activity of the school field recognition program. The extent to which the effectiveness is still being analyzed until now with the hope that it can be used as a basic for taking various policies in making the school field recognition program effectiveness in Unimed.
\end{abstract}

Keywords: Analysis, Meaningfulness, Assistance, Pandemic, Covid-19.

\section{Introduction}

The Internship Program is a mandatory activity for every student in higher education institutions, including State University of Medan. The internship program carried out in the 
Even Semester of the 2020-2021 academic year for students is called as the School Field Recognition Program, which was previously called the Internship Program. If the previous Internship Program was held in even semesters, namely semesters two, four, and six, then this School Field Recognition Program is held in the third or fourth semester. As the first stage, the completion of School Field Recognition Program I will be followed by School Field Recognition Program II in a higher semester.

During the implementation of the Internship program in school units, several scientific studies have been carried out through the previous research which includes research on (1) Perception of Reflection Results on the Implementation of Internship Activities 1 [1]. (2) Analysis of the Contribution of Internship Courses 1 and 2 to Student Commitment to Learning and (3) Analysis of the Impact of Policy Implementation of Internship Programs 1, 2, and 3 on the Decree of the Ministry of Research, Technology and Higher Education No. $123 / \mathrm{M} / \mathrm{Kpt} / 2019$, it can be said that the success of the Internship program 1, 2, and 3 and/or School Field Recognition Program which continues to this day, cannot be separated from the contribution of field supervisors, including Field Guidance Lecturers.

The appointment and/or assignment to supervisors is intended so that School Field Recognition Program can take place effectively, so that the purpose of School Field Recognition Program can be achieved. The achievement of School Field Recognition Program goals absolutely must be accompanied by a systematic mentoring system by the assistants, such as tutors, school unit heads and supervisors. During the previous internship program, from 2017 to 2019, the role of Field Guidance Lecturers was felt by students because Field Guidance Lecturers directly assisted students in the field.

Field Guidance Lecturers's assistance to students has changed since the world (including Indonesia) was hit by the Covid-19 Pandemic. Most of the guidance is done online (on the network) either through Whatsapp, cell phones, google classroom or zoom meetings. Indeed, this determines the success of the School Field Recognition Program program itself. If the location where the internship is held and also the place where Field Guidance Lecturers is located has a good network, the mentoring process will take place effectively, otherwise if it is not good, it can be imagined what could happen. This kind of conditions and situations can certainly cause problems related to the effectiveness of Field Guidance Lecturers assistance to students.

The efforts to anticipate the effectiveness of online School Field Recognition Program mentoring in the future need to be studied in depth about how much the meaning of Field Guidance Lecturers mentoring during the COVID-19 pandemic to School Field Recognition Program 1 students, with the hope that the School Field Recognition Program 2 implementation plan can be adapted to the conditions that will be faced by students in the implementation of this School Field Recognition Program. This is the main reason for this research which entitled " Analysis of The Meaning of Field Supervisor Assistance in The School Field Recognition Program in The Pandemic of Covid-19 At Faculty of Education Universitas Negeri Medan”. Based on the background of the problems stated above, this research problem can be formulated as follows: 1) How are students' perceptions of the Field Guidance Lecturers mentoring process of School Field Recognition Program 1 during the Covid-19 Pandemic at Faculty of Education Unimed? 2) How are students' perceptions of the meaning of Field Guidance Lecturers mentoring while participating in School Field Recognition Program 1 during the Covid-19 Pandemic at Faculty of Education Unimed? 3) What is the impact of Field Guidance Lecturers mentoring on the completion of student activities in the School Field Recognition Program 1 Program during the Covid-19 Pandemic at Faculty of Education Unimed? 


\section{Theory}

\subsection{The Essence of the School Field Introduction Program}

The school field introduction program which was previously known as the internship program, is one of the mandatory courses for students at the State University of Medan. In general, the internship program is defined as part of a training system that is held in an integrated manner between training in the training institutions by working directly under the guidance and supervision of instructors or workers who are more experienced in the process of producing goods and/or services in the company, in order to master the skills or expertise [2].

School Field Recognition Program is a process of observation and internship carried out by students of the Bachelor of Education Program to study about aspects of learning and management of education in education units. School Field Recognition Program is a stage in the process of preparing professional educators (teachers) at the Bachelor of Education level, in the form of assignments to students to implement learning outcomes through observing the learning process in schools/educational institutions, training in developing learning tools, and guided teaching and learning and accompanied by reflective action under the guidance and supervision of supervising lecturers and tutors in stages. This School Field Recognition Program is carried out in three stages, namely (a) School Field Recognition Program 1, (2) School Field Recognition Program 2), and (3) School Field Recognition Program 3.

The purpose of this School Field Recognition Program program is to build a foundation of educator identity for prospective student educators through several forms of activities in schools, which include (a) observation of direct school culture; (b) observation of organizational structure and work procedures in schools; (c) observation and implementation of school rules; (d) observation of formal-ceremonial activities in schools (eg: flag ceremonies, meetings, briefings); (e) observation of routine activities in the form of curricular, co-curricular, and extra-curricular activities; and (f) observation of positive habituation practices and habits in schools.

The achievement of School Field Recognition Program goals can be done through the implementation of various learning activities which include observation, analysis and direct appreciation of activities related to school culture, school management and school dynamics as an educational and learning development institution. The results of activities that must be shown and/or displayed by students during and after participating in School Field Recognition Program 1 include various fields of management of the education and learning system in education units carried out by all educators and education personnel in schools, which include the ability to (1) describe the general characteristics of students which will later become responsibilities in educational practice, (2) describe the organizational structure and work procedures of the school, (3) describe the school rules and regulations, (4) identify the ceremonial-formal activities in schools, (5) identify the routine activities in the form of curricular, co-curricular and extracurricular activities, (6) describe the practices of refraction and positive habits in schools.

\subsection{The Nature of the School Field Recognition Program During the Covid-19 Pandemic}

The implementation of internship activities, such as School Field Recognition Program in universities (such as at Unimed) involves various parties, from university leaders to personal human resource empowerment institutions in the communities where the internship activities 
are carried out. One of the parties who are the spearhead or front line in generating student activities in this School Field Recognition Program is the Field Guidance Lecturer. Supervising lecturers are lecturers who assist students in conducting internships. The role of the supervising lecturer is to guide and direct students in the implementation of the Internship, carry out field supervision, guide the student practitioners in the preparation of learning tools, guide the students in the preparation of the Internship report, test the student practitioners in the implementation of teaching practices and evaluate the activities of the student during practice in the training school. This means that Field Guidance Lecturer is an important element in the implementation of School Field Recognition Program.

Field Guidance Lectureris a lecturer who owns and has fulfilled the academic requirements required by the organizing institution. Requirements that must be met by Field Guidance Lecturer, which include (1) academic qualifications at least a master or applied master and a background in accordance with the scientific field or expertise being taught, (2) non-educational qualified lecturers must have a certificate of skills development learning training Instructional (Pekerti) and/or Applied Approach (AA); (3) has the lowest position of Expert Assistant and (4) proposed by the relevant study program; [3].

The duties and responsibilities carried out by Field Guidance Lecturer are structured in such a way and operationally outlined in the RPS with details as shown in Table 1 below.

Table 1. Description of Field Guidance Lecturer and Student Activities during School Field Recognition Program Learning I.

\begin{tabular}{|c|c|c|c|}
\hline MEETING & SUPERVISORS' ACTIVITIES & STUDENTS' ACTIVITIES & TIME \\
\hline 1 & $\begin{array}{l}\text { Lecturers provide direction to } \\
\text { students on activities: } \\
\text { - Explanation of the Lecture } \\
\text { Contract and RPS } \\
\text { - Explanation of the mechanism } \\
\text { for implementing the internship }\end{array}$ & $\begin{array}{l}\text { Students follow the directions } \\
\text { and explanations of the } \\
\text { lecturer }\end{array}$ & $\begin{array}{c}1 \mathrm{x} \\
100\end{array}$ \\
\hline $2-3$ & $\begin{array}{l}\text { Lecturers provide direction to } \\
\text { students regarding observations, } \\
\text { interviews and document analysis } \\
\text { of the general characteristics of } \\
\text { participants }\end{array}$ & $\begin{array}{l}\text { Students carry out } \\
\text { observations, interviews } \\
\text { document analysis of } \\
\text { general characteristics } \\
\text { students }\end{array}$ & $\begin{array}{c}2 \times \\
170\end{array}$ \\
\hline $4-5$ & $\begin{array}{l}\text { Lecturers provide direction to } \\
\text { students regarding observation, } \\
\text { interviews and analysis of } \\
\text { organizational structure documents } \\
\text { and school work procedures }\end{array}$ & $\begin{array}{l}\begin{array}{l}\text { Students carry } \\
\text { observation the } \\
\text { activities, } \\
\text { interviews and } \\
\text { analysis of } \\
\text { organizational structure } \\
\text { documents and school work } \\
\text { procedures }\end{array} \\
\end{array}$ & $\begin{array}{c}2 \times \\
170\end{array}$ \\
\hline $6-7$ & $\begin{array}{l}\text { Lecturers provide direction to } \\
\text { students regarding observation, } \\
\text { interviews and analysis of school } \\
\text { rules and regulations }\end{array}$ & $\begin{array}{lcc}\text { Students } & \text { carry } & \text { out } \\
\text { observations, interviews } & \text { and } \\
\text { analysis of school rules } & \text { and } \\
\text { regulations } & & \end{array}$ & $\begin{array}{c}2 x \\
170\end{array}$ \\
\hline 8 & \multicolumn{2}{|l|}{$\begin{array}{ll} & \text { Reflection } \\
\end{array}$} & $1 \times 100^{\prime}$ \\
\hline $9-10$ & $\begin{array}{l}\text { Lecturers provide direction to } \\
\text { students regarding interview } \\
\text { observations and document analysis } \\
\text { of formal school ceremonial } \\
\text { activities }\end{array}$ & $\begin{array}{l}\text { Students carry out the } \\
\text { observations, interviews and } \\
\text { document analysis of formal } \\
\text { school ceremonial activities }\end{array}$ & $\begin{array}{c}2 \times \\
170\end{array}$ \\
\hline & Lecturers provide direction to & Students & $2 x$ \\
\hline
\end{tabular}




\begin{tabular}{|c|c|c|c|}
\hline $11-12$ & $\begin{array}{l}\text { students regarding interview } \\
\text { observations and document analysis } \\
\text { of intracurricular, co-curricular and } \\
\text { extracurricular activities. }\end{array}$ & $\begin{array}{l}\text { observations, interviews and } \\
\text { document analysis of intra- } \\
\text { curricular, co-curricular and } \\
\text { extra-curricular activities. }\end{array}$ & $170^{\prime}$ \\
\hline $13-14$ & $\begin{array}{l}\text { Lecturers provide direction to } \\
\text { students about observation, } \\
\text { interviews and document analysis, } \\
\text { practice of refraction and positive } \\
\text { habits in schools }\end{array}$ & $\begin{array}{l}\text { Students carry out } \\
\text { observations, interviews and } \\
\text { document analysis of practice } \\
\text { documents of refraction and } \\
\text { positive habits at school }\end{array}$ & $\begin{array}{c}2 \mathrm{x} \\
170^{\prime}\end{array}$ \\
\hline 15 & \multicolumn{2}{|c|}{ Reflection } & $1 \times 100^{\prime}$ \\
\hline 16 & \multicolumn{2}{|c|}{ Exam } & $1 \times 100^{\prime}$ \\
\hline
\end{tabular}

Based on the description of Field Guidance Lecturer and student activities in Table 1 above, it can be seen that Field Guidance Lecturer mentoring greatly determines student success in the School Field Recognition Program 1 program. Therefore, it can be said that Field Guidance Lecturer mentoring in this School Field Recognition Program must be meaningful for students. Meaningful in this case means that the process of Field Guidance Lecturer mentoring must be felt directly by students at every learning activity.

Factors that allow less intensive and/or effective Field Guidance Lecturer mentoring for students are the situations that prevent direct interaction between Field Guidance Lecturer and students when students have to carry out their learning activities, such as restrictions on both intensity and distance between the two parties due to natural disasters, such as the covid-19 pandemic. Visits and meetings between Field Guidance Lecturer and students, one student with another student, Field Guidance Lecturer and students with managers and residents of the institution where School Field Recognition Program 1 is located, students with students or learning residents are all limited so that students do not seem to get maximum assistance and guidance. This situation certainly has an impact on the achievement of the ultimate goal of School Field Recognition Program 1 itself. Even this situation can occur, but Field Guidance Lecturer in accordance with the duties and responsibilities that have been entrusted to carry out must be committed to continue to assist and guide students through various communication channels, such as zoom meetings, WhatsApp, google meet, cell phones, and virtual communication tools. other.

The mentoring of School Field Recognition Program 1 students by Field Guidance Lecturer through virtual certainly has a different meaning from direct mentoring. Through offline, Field Guidance Lecturer and students can directly witness and feel everything that has been done or achieved by students, but it will be different through online. When communicating by virtual, there are many limitations that can be experienced, both physical appearance, sound, smooth communication, and so on, not to mention if there is a network disturbance.

Based on the mindsetabove, it can be synthesized that the analysis of the significance of Field Guidance Lecturer mentoring for students participating in School Field Recognition Program 1 during the Covid-19 pandemic may be different when compared to normal times. The significance of the Covid-19 pandemic needs to be analyzed in such a way that in the implementation of the next School Field Recognition Program 2 stage, so it can facilitate students as they should through maximum assistance and guidance by professional Field Guidance Lecturer, whatever the situation is currently being faced during the Covid-19 pandemic. This needs to be studied academically or scientifically through research with the following paradigm: 
Covid-19 pandemic situation

Significance

Fig. 1. The Impact of the Covid-19 Pandemic on the Meaning of Guidance.

Based on the theoretical framework and thinking framework above, so the operational questions posed in this study are: (1) How are students' perceptions of the Field Guidance Lecturer mentoring process of School Field Recognition Program 1 during the Covid-19 Pandemic at Faculty of Education Unimed?, (2) How are students' perceptions of the meaning of Field Guidance Lecturer mentoring while participating in School Field Recognition Program 1 during the Covid-19 Pandemic at Faculty of Education Unimed?, (3) What is the impact of Field Guidance Lecturer mentoring on the completion of student activities in the School Field Recognition Program 1 Program during the Covid-19 Pandemic at Faculty of Education Unimed?

\section{Method}

This research used quantitative descriptive study that emphasizes its analysis on the numbers from the calculations to find the values of student perceptions of the significance of Field Guidance Lecturer mentoring in School Field Recognition Program 1 activities at Faculty of Education Unimed. This study was designed to analyze whether or not there was an impact of the covid 19 pandemic on the significance of Field Guidance Lecturer mentoring on the learning activities of School Field Recognition Program 1 participant students as a continuation of the results of previous research.

This research was conducted from April to August 2021 at Faculty of Education Unimed. The population in this study were all Faculty of Education Unimed students for the 2020/2021 Academic Year who had taken School Field Recognition Program 1 Course, totaling 565 people. The sample of this study was drawn randomly with a random technique with a percentage rate of 20 percent, so that the number of samples reached 146 people. The instrument used in collecting data in this study was a questionnaire, with the following grid.

Table 2. Grid of Research Variable Instruments.

\begin{tabular}{|c|c|c|c|c|c|}
\hline \multirow[t]{2}{*}{ Variable } & \multirow[t]{2}{*}{ Indicator } & \multicolumn{3}{|c|}{ Aspect } & \multirow{2}{*}{$\begin{array}{l}\text { Item } \\
\text { Total }\end{array}$} \\
\hline & & Process & Significant & Impact & \\
\hline \multirow{4}{*}{$\begin{array}{l}\text { Field } \\
\text { Guidance } \\
\text { Lecturer } \\
\text { Mentoring }\end{array}$} & 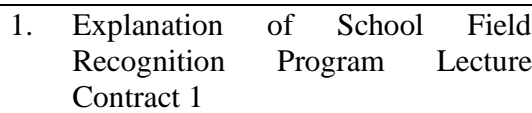 & $1,2,3,4$ & 1 & 1 & 6 \\
\hline & $\begin{array}{l}\text { 2. Implementation of observations, } \\
\text { interviews and document analysis of } \\
\text { the general character of students }\end{array}$ & $5,6,7$ & 2,3 & 2,3 & 7 \\
\hline & $\begin{array}{l}\text { 3. Implementation of observations, } \\
\text { interviews and analysis of } \\
\text { organizational structure documents } \\
\text { and school work procedures }\end{array}$ & 8.9 & 4,5 & 4,5 & 6 \\
\hline & $\begin{array}{l}\text { 4. Implementation of observations, } \\
\text { interviews and analysis of school } \\
\text { rules and regulations }\end{array}$ & 10,11 & 6,7 & 6,7 & 6 \\
\hline
\end{tabular}




\begin{tabular}{|c|c|c|c|c|c|}
\hline & $\begin{array}{l}\text { 5. Implementation of the Reflection on } \\
\text { the results of Phase I observations }\end{array}$ & 12,13 & 8,9 & 8,9 & 6 \\
\hline & $\begin{array}{l}\text { 6. Observation and interview analysis } \\
\text { of formal school ceremonial } \\
\text { activities }\end{array}$ & $\begin{array}{l}14,15, \\
16,\end{array}$ & 10 & 10 & 5 \\
\hline & $\begin{array}{l}\text { 7. Implementation of Observations, } \\
\text { interviews and document analysis }\end{array}$ & $\begin{array}{c}17, \\
18,19,\end{array}$ & 11,12 & 11,12 & 7 \\
\hline & $\begin{array}{l}\text { 8. Implementation of the Reflection on } \\
\text { the results of Phase II observations }\end{array}$ & 20,21 & 13 & 13 & 4 \\
\hline
\end{tabular}

\section{Results and Discussion}

The data from the analysis of the significance analysis of Field Supervisor Assistance in the Field Recognition Program during Pandemic Covid-19 at the Faculty of Education, Unimed can be described as follows:

\subsection{Perception Data on Field Guidance Lecturer Guidance Process}

The presentation of data about the Field Guidance Lecturer Mentoring Process for students while participating in School Field Recognition Program 1 during the Pandemic of Covid-19 at Faculty of Education Unimed is presented in Table 3 and table 4 below.

Table 3. Frequency Distribution of Perception Data on Field Guidance Lecturer Guiding Process.

\begin{tabular}{|l|c|c|c|c|}
\hline No & Interval Class & Frequency & Relative Frequency & $\begin{array}{c}\text { Cumulative } \\
\text { Frequency }\end{array}$ \\
\hline 1 & $1.0-1.8$ & 0 & $0 \%$ & $0 \%$ \\
\hline 2 & $1.9-2.6$ & 0 & $0 \%$ & $0 \%$ \\
\hline 3 & $2.7-3.4$ & 0 & $0 \%$ & $0 \%$ \\
\hline 4 & $3.5-4.2$ & 94 & $64.82 \%$ & $64.82 \%$ \\
\hline 5 & $4.3-5.0$ & 51 & $35.18 \%$ & $100 \%$ \\
\hline & Total & 100 & $100 \%$ & $100 \%$ \\
\hline
\end{tabular}

Based on the data frequency in Table 3 above, it can be seen that according to the perception of students the Field Guidance Lecturer mentoring process during School Field Recognition Program 1 during the Pandemic of Covid-19 at Faculty of Education Unimed was classified as effective with data trends as shown in Table 4 below.

Table 4. Tendency of Perception Data on the Field Guidance Lecturer Mentoring Process.

\begin{tabular}{|l|l|l|c|c|}
\hline No. & \multicolumn{1}{|c|}{ Score Range } & \multicolumn{1}{|c|}{ Criteria } & Total & Percentage \\
\hline 1. & $4.00-5.00$ & Very Effective & 116 & $80 \%$ \\
\hline 2. & $3.00-3.99$ & Effective & 29 & $20 \%$ \\
\hline 3. & $2.00-2.99$ & Less Effective & 0 & $0 \%$ \\
\hline 4. & $1.00-1.99$ & Not Effective & 0 & $0 \%$ \\
\hline \multicolumn{3}{|c|}{ Total } & 145 & $100 \%$ \\
\hline \multicolumn{4}{|c|}{ Less category percentage } & $100 \%$ \\
\hline \multicolumn{4}{|c|}{} \\
\hline
\end{tabular}


Based on the data in Table 4 above, it can be seen that the mentoring process that was planned to be carried out in the School Field Recognition Program 1 implementation during the Pandemic of Covid-19 at Faculty of Education Unimed according to the participating students was very effective.

\subsection{Data on the Significance of Field Guidance Lecturer Mentoring Perceptions}

The presentation of data on the significance of Field Guidance Lecturer Mentoring for students while participating in School Field Recognition Program 1 during the Covid-19 Pandemic at Faculty of Education Unimed is presented in Table 5 below.

Table 5. Frequency Distribution of Perceived Data on Significance Field Guidance Lecturer Mentoring.

\begin{tabular}{|c|c|c|c|c|}
\hline No & Interval Class & Frequency & $\begin{array}{c}\text { Relative } \\
\text { Frequency }\end{array}$ & $\begin{array}{c}\text { Cumulative } \\
\text { Frequency }\end{array}$ \\
\hline 1 & $1.0-1.8$ & 0 & $0 \%$ & $0 \%$ \\
\hline 2 & $1.9-2.6$ & 0 & $0 \%$ & $0 \%$ \\
\hline 3 & $2.7-3.4$ & 0 & $0 \%$ & $0 \%$ \\
\hline 4 & $3.5-4.2$ & 82 & $56.55 \%$ & $56.55 \%$ \\
\hline 5 & $4.3-5.0$ & 63 & $43.45 \%$ & $100 \%$ \\
\hline & Total & 100 & $100 \%$ & $100 \%$ \\
\hline
\end{tabular}

Based on the frequency of data in Table 5 above, it can be seen that students' perceptions of the significance of Field Guidance Lecturer mentoring during School Field Recognition Program 1 during the Covid-19 Pandemic at Faculty of Education Unimed were quite significant with the tendency of data as shown in Table 6 below.

Table 6. The Tendency of Perception Data on Significance Field Guidance Lecturer Mentoring.

\begin{tabular}{|l|c|c|c|c|}
\hline No. & Score Range & Criteria & Total & Percentage \\
\hline 1. & $4.00-5.00$ & Very Good & 111 & $77 \%$ \\
\hline 2. & $3.00-3.99$ & Good & 34 & $23 \%$ \\
\hline 3. & $2.00-2.99$ & Less & 0 & $0 \%$ \\
\hline 4. & $1.00-1.99$ & Very Less & 145 & $0 \%$ \\
\hline \multicolumn{3}{|c|}{ Percentage of good category } & $100 \%$ \\
\hline \multicolumn{3}{|c|}{ Less category percentage } & $0 \%$ \\
\hline
\end{tabular}

Based on the data in Table 6 above, it can be seen that the mentoring carried out by Field Guidance Lecturer during the implementation of School Field Recognition Program 1 during the Pandemic of Covid-19 at Faculty of Education Unimed according to the participating students was very meaningful. 


\subsection{Data on the Impact of Field Guidance Lecturer Guidance on the completion of Student Activities}

The presentation of data about the Field Guidance Lecturer Mentoring Process for students during School Field Recognition Program 1 during the Pandemic of Covid-19 at Faculty of Education Unimed is presented in Table 6 below.

Table 6. Frequency Distribution of Field Guidance Lecturer Mentoring Impact Data Regarding the Completion of Student Activities.

\begin{tabular}{|c|c|c|c|c|}
\hline No & Interval Class & Frequency & Relative Frequency & $\begin{array}{c}\text { Cumulative } \\
\text { Frequency }\end{array}$ \\
\hline 1 & $1.0-1.8$ & 0 & $0 \%$ & $0 \%$ \\
\hline 2 & $1.9-2.6$ & 0 & $0 \%$ & $0 \%$ \\
\hline 3 & $2.7-3.4$ & 0 & $0 \%$ & $0 \%$ \\
\hline 4 & $3.5-4.2$ & 82 & $56.55 \%$ & $56.55 \%$ \\
\hline 5 & $4.3-5.0$ & 63 & $43.45 \%$ & $100 \%$ \\
\hline & Total & 100 & $100 \%$ & $100 \%$ \\
\hline
\end{tabular}

Based on the frequency of data in Table 6 above, it can be seen that students' perceptions of the impact of Field Guidance Lecturer mentoring during School Field Recognition Program 1 during the Pandemic of Covid-19 at Faculty of Education Unimed on student School Field Recognition Program activities were classified as high with data tending to be as shown in Table 7 below.

Table 7. The Tendency of Perception Data on Impact of Field Guidance Lecturer Mentoring Towards School Field Recognition Program 1 Student Activities.

\begin{tabular}{|c|c|c|c|c|}
\hline No. & Score Range & Criteria & Total & Percentage \\
\hline 1. & $4.00-5.00$ & Very Impactful & 116 & $80 \%$ \\
\hline 2. & $3.00-3.99$ & Impactful & 29 & $20 \%$ \\
\hline 3. & $2.00-2.99$ & Less Impactful & 0 & $0 \%$ \\
\hline 4. & $1.00-1.99$ & No Impactful & 0 & $0 \%$ \\
\hline \multicolumn{3}{|c|}{ Total } & 145 & $100 \%$ \\
\hline \multicolumn{4}{|c|}{ Percentage of good category } & $100 \%$ \\
\hline \multicolumn{4}{|c|}{ Less category percentage } & $0 \%$ \\
\hline
\end{tabular}

The mentoring of School Field Recognition Program 1 students by Field Guidance Lecturer through virtual certainly has a different meaning from direct mentoring. The findings of this study indicate that online Field Guidance Lecturer mentoring is almost no different from offline, where in the student's perception the School Field Recognition Program I mentoring process can take place very effectively. This means that Field Guidance Lecturer does not view or make the Covic-19 Pandemic situation an obstacle in guiding students. Field Guidance Lecturer continues to accompany students in every step and activity of School Field Recognition Program students. The mentoring process can take place as programmed by the institution.

Field Guidance Lecturer mentoring during the School Field Recognition Program, according to student perceptions is very meaningful with an average value of 4.37 . This means 
that Field Guidance Lecturer mentoring during the Covid-19 pandemic can help students in carrying out their School Field Recognition Program activities. The mentoring is quite meaningful for students. This significance certainly gives a signal that the Field Guidance Lecturer supervisor really carry out the School Field Recognition Program in a responsible and highly committed manner. Field Guidance Lecturer 's efforts in assisting School Field Recognition Program during the Covid-19 pandemic have had a positive impact on student activities. The impact of Field Guidance Lecturer mentoring on the completion of the School Field Recognition Program Program can reach 78.65 percent, while the magnitude of the significance of Field Guidance Lecturer Guidance on the impact of Field Guidance Lecturer mentoring on the completion of the School Field Recognition Program reaches 75.6 percent.

\section{Conclusion}

Based on the results of data management and analysis, it can be concluded that: 1) Student perceptions of the Field Guidance Lecturer mentoring process during School Field Recognition Program 1 during the Covid-19 Pandemic at Faculty of Education Unimed were classified as very effective with an average score of $4.19,2$ ) Student perceptions of the significance of Field Guidance Lecturer mentoring during School Field Recognition Program 1 during the Covid-19 Pandemic at Faculty of Education Unimed belonged to the very effective category with an average score of 4.37,3) The impact of Field Guidance Lecturer mentoring on the completion of student activities in the School Field Recognition Program 1 Program during the Covid-19 Pandemic at Faculty of Education Unimed is in the high category, the contribution amount is 75.6 percent at a significant level of 95 percent.

\section{References}

[1] Wau, Yasaratodo, Anifah, Kurniawan F. Persepsi Tentang Hasil Refleksi Penyelenggaraan Kegiatan Magang 1 dan Hubungannya dengan Komitmen Mahasiswa Membekali Diri Menjadi Calon Tenaga Pendidikan di Program Studi Pendidikan Luar Sekolah FIP Unimed. 2017.

[2] Regulation of the Minister of Manpower and Transmigration No. Per.22/Men/IX/2009 concerning Implementation of Domestic Internship.

[3] Unimed. Buku Panduan Program Pengenalan Lapangan Persekolahan Program Sarjana Pendidikan. Medan: LPPM; 2020. 